\title{
Victor Brombert, Stendhal. Roman et liberté
}

\author{
Michel Arrous
}

\section{(2) OpenEdition}

\section{Journals}

\section{Édition électronique}

URL : http://journals.openedition.org/studifrancesi/7617

DOI : 10.4000/studifrancesi. 7617

ISSN : 2427-5856

\section{Éditeur}

Rosenberg \& Sellier

\section{Édition imprimée}

Date de publication : 1 décembre 2009

Pagination : 644

ISSN : 0039-2944

\section{Référence électronique}

Michel Arrous, "Victor Brombert, Stendhal. Roman et liberté », Studi Francesi [En ligne], 159 (LIII | III) | 2009, mis en ligne le 30 novembre 2015, consulté le 08 janvier 2021. URL : http://

journals.openedition.org/studifrancesi/7617 ; DOI : https://doi.org/10.4000/studifrancesi.7617

Ce document a été généré automatiquement le 8 janvier 2021.

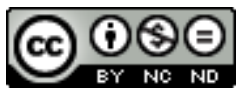

Studi Francesi è distribuita con Licenza Creative Commons Attribuzione - Non commerciale - Non opere derivate 4.0 Internazionale. 


\title{
Victor Brombert, Stendhal. Roman et liberté
}

\author{
Michel Arrous
}

\section{RÉFÉRENCE}

VICTOR BROMBERT, Stendhal. Roman et liberté, Paris, Éditions de Fallois, 2007, pp. 164.

1 Victor Brombert dont on se rappelle la thèse intitulée Stendhal et la voie oblique, qui parut en 1954, un peu dans l'ombre du grand livre de Georges Blin, publie sa propre version, en français, du second ouvrage qu'il a consacré à son auteur favori, Stendhal: Fiction and the Themes of Freedom (1968), lequel figure rarement au catalogue des bibliothèques universitaires. Plus qu'une traduction, il s'agit en fait d'une réécriture élégante qui témoigne d'une lecture attentive des grands motifs stendhaliens, entre autres la quête de la sincérité et l'estime de soi, la liberté et ses paradoxes. On regrettera que V. Brombert n'ait pas tiré parti des travaux critiques récents. 